\title{
ANALISIS PENYELESAIAN SENGKETA DALAM KEGIATAN USAHA JASA KEUANGAN PASAR MODAL DI INDONESIA
}

\author{
Oleh: \\ AMANDA INDAH PRAMESURI SURALAGA \\ Fakultas Hukum Universitas Bandar Lampung \\ Jl. ZA Pagar Alam No 26 Labuhan Ratu Bandar Lampung \\ Email: amandapramesuri@yahoo.com
}

\begin{abstract}
ABSTRAK
Capital Markets can also be interpreted as a professional institution that deals with securities buying and selling transactions, the capital market as a long-term investment tool that is currently becoming a trend in the community. But it cannot be denied that along with the development of the capital market in Indonesia it has caused problems or also disputes in the process of capital market activities in Indonesia. The problem in this research is how do the procedures and dispute resolution processes in business activities in the financial services sector after the procedures and processes in the settlement of Capital Market disputes, we must also know the legal consequences of the disputes in the financial services business of the Capital Market? The research method used a normative and empirical juridical approach, the data used are secondary data and primary data. Studies conducted with literature studies and field studies, data analysis used is qualitative juridical. The results show that the procedure and capital market dispute resolution process can be carried out either litigation or non-litigation, but the joint parties usually choose a non-litigation path in the procedure, if through non-litigation the parties must go through internal mediation first if the internal mediation fails involving the Financial Services Authority (OJK) as a facilitator in the process of resolving the problems after the process at the financial services authority did not get an agreement, the settlement could be continued through the Sengekta Alternative Settlement Agency (LAPS) and the Capital Market Arbitration Agency (BAPMI).
\end{abstract}

Keywords: Settlement; Dispute; Business activities; Financial services; Capital market.

\section{PENDAHULAN}

Negara Indonesia adalah Negara yang sedang berkembang. Sebagai Negara yang sedang berkembang Indonesia saat ini tengah berupaya melakukan pembangunan disegala bidang guna meningkatkan pertumbuhan ekonomi Negara. Untuk melaksanakan pembangunan ekonomi nasional diperlukan biaya yang tidak sedikit, kebutuhan besar dalam pembangunan ekonomi nasional tidak dapat dibiayai oleh pemerintah saja baik melalui penerimaan pajak dan penerimaaan lainya (Jusuf Anwar. 2005:1).

\begin{tabular}{llr}
\multicolumn{1}{c}{ Salah satu alternatif } & sumber \\
pembiayaan & pembangunan & ekonomi \\
nasional adalah melalui pasar modal. Pasar
\end{tabular}

modal sama halnya dengan pasar pada umumnya yaitu merupakan tempat bertemunya penjual dan pembeli, hanya saja yang membedakannya dengan pasar pada umunya yaitu dalam pasar modal yang diperjual belikan adalah berbagai macam instrument keuangan jangka panjang baik dalam bentuk obligasi maupun saham. Pasar modal berfungsi menghubungkan investor, perusahaan dan institusi pemerintah melalui perdagangan instrument keuangan jangka panjang (Jusuf Anwar. 2008:27).

Dalam kegiatan di pasar modal terkadang sering dijumpai adanya pelanggaran-pelanggaran. Jenis pelanggaran di bidang pasar modal dapat dikategorikan menjadi dua kelompok yaitu 
yang bersifat teknis administratif, seperti tidak menyampaikan atau terlambat menyampaikan laporan dan atau dokumen, menjalankan kegiatan di pasar modal tanpa memperoleh persetujuan atau perizinan dari lembaga pengawas di pasar modal dan pelanggaran- pelanggaran yang bersifat khas pasar modal seperi manipulasi pasar, insider trading dan praktik penipuan di pasar modal. Pelanggaran di bidang pasar modal termasuk ke dalam jenis kejahatan yang unik, keunikan ini dapat dilihat baik dari jenis pelanggarannya, dari sisi pelakunya yang berpendidikan dan sangat rapi modus kerjanya. Apabila dituangkan dalam bentuk matriks akan terlihat bahwa pihakpihak yang sangat berpotensi menjadi pelaku adalah mereka yang menduduki posisi strategis dalam perusahaan (direksi, komisaris atau pejabat setingkat manager lainnya), para professional seperti broker, penasihat investasi, akuntan, lawyer dan penilai, atau bahkan emiten atau perusahaan publik yang bersangkutan.

Menurut Tavinayati dan Yulia Qamariyanti. (2009:11) Pengertian pasar modal, dalam kegiatan transaksi usaha dapat ditemui sebuah sarana investasi yang belakangan ini disebut sebagai pasar modal. Pasar modal sendiri adalah sebuah lembaga keuangan negara yang kegiatannya dalam hal penawaran dan perdagangan efek (surat berharga). Pasar modal bisa diartikan sebuah lembaga profesi yang berhubungan dengan transaksi jual beli efek dan perusahan publik yang berkaitan dengan efek. Sehingga pasar modal biasa dikenal sebagai tempat bertemunya penjual dan pembeli modal atau dana. Pasar modal sebagaimana pasar pada umumnya adalah suatu tempat untuk mempertemukan penjual dan pembeli. Yang membedakannya dengan pasar lainnya adalah pada objek yang diperjual belikan. Kalau pada pasar lainnya yang diperdagangkan adalah sesuatu yang sifatnya konkret seperti kebutuhan seharihari, tetapi yang diperjual belikan dipasar modal adalah modal atau dana dalam bentuk efek (surat berharga) pasar modal di Indonesia.

Sedangkan menurut Pasal 1 butir (14) Undang-Undang Pasar Modal Nomor 8 Tahun 1995 tantang Pasar Modal definisi Pasar modal adalah kegiatan yang bersangkutan dengan penawaran umum perdagangan efek, perusahaan publik yang berkaitan dengan efek yang telah diterbitkan, serta lembaga dan profesi yang berkaitan dengan efek. Menurut Ana Rokhmatssa (2017:6) pengertian Pasar Modal (capital market) adalah pasar untuk berbagai instrumen keuangan jangka panjang yang bisa diperjualbelikan, baik dalam bentuk utang, ekuitas (saham), instrumen derivatif, maupun instrumen lainnya. Pasar modal merupakan sarana pendanaan bagi perusahaan maupun institusi lain (misalnya pemerintah) dan sarana bagi kegiatan berinvestasi.

Salah satu tujuan dibentuknya Otoritas Jasa Keuangan (OJK) adalah untuk melindungi kepentingan konsumen dan masyarakat dalam melakukan kegiatan dalam sektor jasa keuangan. Perlindungan konsumen yang diamanahkan kepada Otoritas Jasa keuangan (OJK) disebutkan secara eksplisit dalam Pasal 4 UndangUndang Nomor 21 Tahun 2011 tentang Otoritas Jasa Keuangan yang dinyatakan sebagai berikut, "OJK dibentuk dengan tujuan agar keseluruhan kegiatan di dalam sektor jasa keuangan mampu melindungi kepentingan konsumen dan masyarakat."

Perlindungan Konsumen di sektor jasa keuangan bertujuan untuk menciptakan sistem perlindungan konsumen yang andal, 
meningkatkan pemberdayaan konsumen dan menumbuhkan kesadaran Pelaku Usaha Jasa Keuangan mengenai pentingnya perlindungan konsumen sehingga mampu meningkatkan kepercayaan masyarakat pada sektor jasa keuangan. Selain itu pula terdapat aturan baru untuk lebih memberikan rasa aman terhadap konsumen Otoritas Jasa Keuangan menerbitkan peraturan baru yaitu Peraturan Otoritas Jasa keuangan Nomor 18/POJK.07/2018 tentang Layanan Pengaduan Konsumen Di Sektor Jasa Keuangan dimana peratuturan tersebut diterbitkan guna untuk mewujudkan kegiatan di sektor jasa keuangan yang mampu melindungi kepntingan konsumen dan masyarakat. Dalam Peraturan Otoritas Jasa Keuangan Nomor 18.POJK.07/2018 tentang Layanan Pengaduan Konsumen Di Sektor Jasa Keuangan terdapat ruang lingkup layanan pengaduan yang terdiri dari peneriaman pengaduan, penanganan pengaduan, penyelesaian sengketa. Para Pelaku Usaha Jasa keungan (PUJK) dilarang mengenakan biaya layanan pengaduan kepada konsumen.

Dalam bagian penjelasan umum dari Undang-Undang Nomor 30 Tahun 1999 tentang Alternatif Penyelesaian sengketa ditentukan bahwa alternatif penyelesaiaan sengketa dilakukan melalui musyawarah para pihak yang bersengketa. Alternatif penyelsian sengketa atau beda pendapat melalui prosedur yang disepakati para pihak, yakni penyelesaian diluar pengadilan dengan cara konsultasi, negosiasi, mediasi, konsuliasi, penilain ahli. Tetapi sebenarnya yang dimaksud dengan alternatif penyelesaian sengketa tersebut termasuk semua jenis penyelesaian sengketa diluar pengadilan Munir fuady, (2003:5).
Dengan banyaknya muncul kejahatan dalam pasar modal, sehingga muncul peran- peran lembaga pengawas di sektor jasa keuangan yang terintegrasi dimana lembaga tersebut yang semula adalah Badan Pengawas Pasar Modal dan Direktorat Jendaral Lembaga Keuangan (Bapepam-LK) berganti menjadi Otoritas Jasa Keuangan (OJK), sesuai dengan peralihan pengawasan di sektor jasa keuangan dimana pasar modal temasuk didalam instrumen jasa keuangan. Sejak disahkannya Undang-Undang Nomor 21 Tahun 2011 tentang Otoritas Jasa Keuangan, maka segala bentuk perizinan dan pengawasan beralih dari Bank Indonesia (BI) dan juga Badan Pengawas Pasar Modal dan Direktorat Jendaral Lembaga Keuangan (Bapepam-LK) menjadi kewenangan sepenuhnya hak Lembaga Otoritas Jasa Keuangan (OJK). Sesuai dengan bunyi pada Pasal 1 UndangUndang Nomor 21 Tahun 2011 tentang Otoritas Jasa Keuangan yaitu:

"Otoritas Jasa Keuangan, yang selanjutnya disingkat OJK, adalah lembaga yang independen dan bebas dari campur tangan pihak lain, yang mempunyai fungsi, tugas, dan wewenang pengaturan, pengawasan, pemeriksaan, dan penyidikan sebagaimana dimaksud dalam Undang- Undang ini”.

Dalam pasal tersebut jelas bahwa Otoritas Jasa Keuangan adalah Lembaga independen yang memiliki fungsi, tugas, wewenang pengaturan, pengawasan, pemeriksaan, penyidikan sehigga jika terjadi sengketa dalam pasar modal maka sesuai dengan Undang-Undang Nomor 21 Tahun 2011 tentang Otoritas Jasa keuangan maka sengketa yang terjadi dalam Pasar Modal bisa diselesaiakan melalui Otoritas Jasa Keuangan (OJK). 
Berkaitan dengan prosedur dan proses penyelesaian sengketa dalam kegiataan usaha jasa keuangan pasar modal di Indonesia yang mungkin diperlukan syaratsyarat tertentu yang dapat ditempuh para pihak-pihak yang bersengketa dalam kegiatan usaha jasa keuangan pasar modal sehingga para pihak dalam industri jasa keuangan. Pasar Modal dapat mengetahui dan memahami prosedur dan proses penyelesaian sengketa tersebut sesuai dengan ketentuan dan peraturan yang berlaku, serta mengetahui akibat hukum bagi para pihak yang bersengketa dalam kegiatan usaha jasa keuangan pasar modal di Indonesia. Penyelesaian sengketa yang berlarut-larut dan masih banyaknya para palaku kegiatan di sektor jasa keuangan yag tidak mengetahui bahwa sengketa yang terjadi dapat diselesaikan melalui Non litigasi atau Lembaga Negara Independen. Berdasarkan hal-hal tersebut, maka penulis tertarik untuk melakukan penelitian yang dituangkan dalam skripsi dengan judul "Analisis Penyelesaian Sengketa Dalam Kegiataaan Usaha Pasar Modal Di Indonesia'.

Berdasarkan uraian di atas, yang menjadi permasalahan dalam penelitian ini adalah:

a. Bagaimana prosedur dan proses penyelesian sengketa dalam kegiatan usaha di sektor jasa keuangan pasar modal ?

b. Bagaimana akibat hukum bagi para pihak yang bersengketa dalam kegiataan usaha jasa keuangan Pasar Modal ?

\section{PEMBAHASAN}

\section{A. Prosedur dan Proses Dalam Kegiatan Usaha Jasa Keuangan Pasar Modal Di Indonesia}

Sengketa adalah perselisihan antara konsumen dengan Lembaga Jasa Keuangan dalam kegiatan penempatan dana oleh konsumen pada Lembaga Jasa Keuangan dan/atau pemanfaatan pelayanan dan/atau produk Lembaga Jasa Keuangan setelah melalui proses penyelesaian pengaduan oleh Lembaga Jasa Keuangan.

Pasar Modal merupakan kegiatan yang berhubungan dengan penawaran umum dan perdagangan efek, perusahaan publik yang berkaitan dengan efek yang diterbitkannya, serta lembaga dan profesi yang berkaitan dengan efek Berdasarkan hasil wawancara dengan Milado Pani selaku Kasubag Pengawasan Pasar Modal pada Kantor Otortitas Jasa Keuangan (OJK) Provinsi Lampung menyatakan bahwa ketika terjadi sengketa dalam pasar modal dimana sengketa itu melibatkan perusahan efek dengan pemilik saham, yang dimana sengketa tersebut terkadang berasal dari jumlah nilai saham dan juga faktor seperti menggunakan data fiktif untuk bertransaksi dengan nasabah, menjual reksa dana nasabah tanpa sepengetahuan nasabah, ridim cash. Maka pemilik saham mempunyai hak untuk mengadukan permasalahan atau sengketa yang terjadi dengan perusahan efek kepada Otoritas Jasa Keuangan (OJK), tetapi konsumen wajib melakukan upaya penyelesaian sengketa secara internal kepada Pelaku Usaha Jasa Keuangan (PUJK), jika penyelesaian secara internal itu tidak terjadi kesepakatan maka konsumen bisa melaporkan kepada Otoritas Jasa Keuangan (OJK) yang akan bertindak sebagai fasilitator terhadap 
kedua pihak yang bersengketa, jika sengketa itu ada pada bidang perdata maka Otoritas Jasa Keuangan dapat memberikan langkah-langkah yang dapat dilalui oleh kedua pihak tetapi jika sengketa itu ada pada bidang pidana seperti Insaider trading maka sengketa tersebut tidak bisa melalui Non litigasi melainkan harus dengan Litigasi.

Sengketa yang masuk kedalam layanan pengaduan Otoritas Jasa Keuangan akan ditindak lanjuti akan tetapi Otoritas Jasa Keuangan hanya akan sebagai fasilitator saja dimana kedua pihak yang bersengketa akan dipertemukan dan ditanyai mengenai permasalahan yang ada, lalu akan terjadi musyawarah antar kedua pihak yang difasilitasi oleh Otoritas Jasa Keuangan(OJK). Akan tetapi Otoritas Jasa Keuangan tidak mempunyai hak untuk memutus sengketa yang terjadi jika terjadi deadlock antar kedua pihak, maka Otoritas Jasa Keuangan akan menyarankan atau memberikan sengketa tersebut kepada Lembaga Alternatif Penyelesaian Sengketa (LAPS). Tata cara penyelesaian sengketa akan berlaku sesuai dengan peraturan Otoritas Jasa Keuangan Nomor 1/POJK.07/2013 tentang perlindungan konsumen dan juga Peraturan Otoritas Jasa Keuangan Nomor 1/POJK.07/2014 tentang Alternatif Penyelesaian Sengketa.

Perlindungan Konsumen adalah perlindungan terhadap konsumen dengan cakupan perilaku usaha jasa keuangan, sedangkan konsumen adalah pihak-pihak yang menempatkan dananya dan/atau memanfaatkan layanan yang tersedia pada Lembaga Jasa Keuangan khususnya pasar modal yaitu layanan yang dimiliki oleh perusahan efek. Perlindungan Konsumen sesuai dengan Peraturan Otoritas Jasa Keuangan Nomor 1/POJK.07/2013 tentang perlindungan konsumen memiliki prinsip diantaranya adanya transparansi, perlakuan yang adil, kerahasian data informasi konsumen, penanganan penyelesaian sengketa konsumen dengan cepat, adil dan biaya terjangkau.

Sesuai dengan ketentuan yang terdapat dalam Peraturan Otoritas Jasa Keuangan Nomor 1/POJK.07/2013 tentang perlindungan konsumen dimana disebutkan bahwa pelaku usaha wajib memberikan informasi yang akurat terhadap konsumen, ketentuan ini juga mengacu pada prinsip transparansi. Pelaku Usaha Jasa Keuangan dilarang menggunakan strategi pemasaran produk dan/atau layanan yang merugikan konsumen dengan memanfaatkan kondisi konsumen yang tidak memiliki pilihan lain dalam mengambil keputusan.

Pelaku Usaha Jasa Keuangan wajib melaksanakan instruksi konsumen sesuai dengan perjanjian dan ketentuan peraturan perundang-undangan, jika pelaku usaha tidak melaksanakan instruksi tersebut maka pihak ketiga yang bekerja untuk kepentingan Pelaku Usaha Jasa Keuangan wajib bertanggungjawab atas kerugian konsumen yang timbul akibat kesalahan dan/atau kelalaian pengurus/pegawai Pelaku Usaha Jasa Keuangan.

Bahwa rangkaian perlindungan konsumen mencakup edukasi, pelayanan informasi dan pengaduan hingga fasilitasi penyelesaian pengaduan, dalam penyelesaian pengaduan oleh Lembaga Jasa Keuangan seringkali tidak tercapai kesepakatan antara Konsumen dengan Lembaga Jasa Keuangan.

Pelaku Usaha Jasa Keuangan wajib memiliki dan melaksanakan mekanisme pelayanan dan penyelesaian pengaduan bagi Konsumen. Mekanisme pelayanan dan penyelesaian pengaduan sebagaimana dimaksud pada Peraturan Otoritas Jasa 
Keuangan Nomor 1/POJK.07/2013 tentang

Perlindungan Konsumen wajib

diberitahukan kepada Konsumen. Sehinga konsumen mengetahui bahwa jika terdapat sengketa maka konsumen dapat menuntut hak kepada Pelaku Usaha Jasa Keuangan dalam sektor jasa keuangan pasar modal untuk menjalankan mekanisme pelayanan dan penyelesaian pengaduan bagi konsumen.

Dalam penyelesaian pengaduan oleh Lembaga Jasa Keuangan seringkali tidak tercapai kesepakatan antara Konsumen dengan Lembaga Jasa Keuangan, bahwa untuk mengatasi hal tersebut diperlukan Lembaga Alternatif Penyelesaian Sengketa yang mampu menyelesaikan Sengketa secara cepat, murah, adil dan efisien.

Berdarkan uraian diatas, maka dapat dianalisis bahwa sengketa yang ada pada kegiataan usaha sektor jasa keuangan pasar modal dapat dipengaruhi oleh Jumlah Nilai Saham dan juga sengketa yang sering masuk dalam layanan pengaduan Otoritas Jasa Keuangan (OJK) seperti Ridim Cash nasabah, menggunakan data pribadi orang atau data fiktif untuk bertransaksi dengan nasabah, tidak adanya perintah dari nasabah untuk perusahan efek dalam menjual belikan saham, jika terjadi sengketa maka penyelesaiannya bisa melalui Otoritas Jasa Keuangan (OJK) dan bila terjadi deadlock maka sengketa tersebut akan dibawa kepada Lembaga Alternatif Penyelesaian Sengketa (LAPS), adapun beberapa sistem yang harus dipahami oleh Palaku Usaha Jasa Keuangan (PUJK) dan Konsumen sebagaimana terlampir dalam Peraturan Otoritas Jasa Keuangan Nomor 1/POJK.07/2013 tentang Perlindungan Konsumen.

\section{Proses Penyelesaian Sengketa \\ Dalam Kegitaan Pasar Modal Di Indonesia}

Penyelesaian sengketa sektor jasa keuangan Pasar Modal melalui mekanisme Otoritas Jasa Keuangan (OJK) harus diawali dengan penyelesaian sengketa keuangan dengan Pelaku Usaha Jasa Keuangan (PUJK) yang dimana bila dimasukan dalam kegiataan usaha jasa keuangan pasar modal berarti sengketa sebelum masuk kejalur pengaduan Otoritas Jasa Keuangan (OJK) harus diselesaikan terlebih dahalu secara internal antara perusahan efek dengan konsumen melalui cara mediasi secara internal antara kedua pihak.

Jika pada tahap mediasi internal antara perusahan efek dengan konsumen tidak ditemukan keputusan atau deadlock maka konsumen dan Lembaga Jasa Keuangan dapat melakukan penyelesaian sengketa di luar pengadilan atau melalui pengadilan. Penyelesaian sengketa di luar pengadilan sebagaimana dimaksud pada Peraturan Otoritas Jasa Keuangan Nomor 1/POJK.07/2014 tentang Alternatif Penyelesaian Sengketa, jika terjadi sengketa maka penyelesaian dilakukan melalui Lembaga Alternatif Penyelesaian Sengketa, penyelesaian sengketa melalui Lembaga Alternatif Penyelesaian Sengketa bersifat rahasia. Lembaga Jasa Keuangan wajib melaksanakan putusan Lembaga Alternatif Penyelesaian Sengketa.

\section{a. Proses Penyelesaian Sengketa Secara Eksternal Melalui Otoritas Jasa Keuangan.}

Penyelesaian sengketa melalui Otoritas Jasa keuangan (OJK) yang dimana fasilitas terbatas oleh Otoritas Jasa Keuangan adalah dimana ketika sengketa tersebut masuk dalam layanan konsumen 
Otoritas Jasa Keuangan (OJK) maka mekanisme yang terjadi adalah hanya sebatas mediasi antar pihak tetapi Otoritas Jasa Keuangan tidak berhak memutus salah satu bersalah atau tidak, Otoritas Jasa Keuangan akan mengembalikan keputusan kepada kedua pihak, jika kedua pihak masih belum menemukan keputusan untuk sengketa tersebut maka Otoritas Jasa keuangan akan melimpahkan sengketa tersebut kepada Lembaga Alternatif Penyelesaian Sengketa (LAPS) atas dasar persetujuan kedua pihak yang bersengketa.

Apabila dalam proses penyelesaian dalam lingkup Otoritas Jasa keuangan (OJK) ditemukan indikasi bersalah dalam perusahan efek maka Otoritas Jasa Keuangan berhak menindak lanjuti lebih jauh permasalahan tersebut tetapi diluar sengketa antara kedua pihak tersebut, Otoritas Jasa keuangan (OJK) akan memanggil pihak-pihak dalam perusahan efek tersebut lalu akan dilakukan investigasi kelayakan perusahan efek tersebut, jika ditemui indikasi tidak baik maka Otoritas Jasa Keuangan akan memberikan sanksi terhadap perusahan efek tersebut. Dan bila ada indikasi pidana dalam sengketa tersebut maka Otoritas Jasa Keuangan (OJK) hanya akan menjadi rekanan hukum untuk proses hukum yang berjalan.

Berdasrkan hasil wawancara dengan Milado Pani selaku Kasubag Pengawasan Pasar Modal Kantor Otoritas Jasa Keuangan (OJK) Provinsi Lampung menyatakan bahwa sengketa Pasar Modal yang ada banyak yang berasal dari sengketa perusahan efek dengan konsumen yang dimana perusahan efek biasanya akan memilih jalur non litigasi untuk penyelesaian sengketa tersebut, dikarenakan penyelesaian non litigasi tidak memakan waktu yang lama, biaya relative terjangkau dan kecil kemungkinan kasus akan terekspos kepihak ketiga yang dapat mempengaruhi citra perusahan dan juga harga saham pada bursa efek.

Dapat dikatakan bahwa penyelesaian sengketa non litigasi melalui Otoritas Jasa Keuangan hanya bersifat fasilitasi terbatas yaitu mediasi tetapi Otoritas Jasa Keuangan tidak berhak memutuskan atau memberikan keputusan terhadap kedua pihak yang bersengketa. Jika kedua pihak masih ingin melanjutkan penyelesaian sengketa kembali maka Otoritas Jasa Keuangan akan memberikan penjelasan mengenai Lembaga Alternatif Penyelesaian Sengketa (LAPS), bila kedua pihak setuju jika sengketa tersebut diselesaikan melalui Lembaga Alternatif Penyelesaian Sengketa (LAPS) maka Otoritas Jasa Keuangan akan memberika sengketa tersebut kepada Lembaga Alternatif Penyelesaian Sengketa (LAPS).

Tetapi harus dipahami bahwa Lembaga Alternatif Penyelesaian Sengketa harus mempunyai layanan penyelesaian sengketa paling kurang berupa mediasi, ajudikasi, arbitrase. Menerapkan prinsip aksesibilitas, independensi, keadilan dan efisiensi dan efektifitas dalam setiap peraturannya, didirikan oleh Lembaga Jasa Keuangan yang dikoordinasikan oleh asosiasi dan/atau didirikan oleh lembaga yang menjalankan fungsi self regulatory organization.

\section{b. Penyelesaian Sengketa Melalui Lembaga Alternatif Penyelesaian Sengketa LAPS}

Dalam interaksi antara konsumen dengan Lembaga Jasa Keuangan (LJK) yang dinamis ditambah dengan jumlah produk dan layanan jasa keuangan yang selalu berkembang, kemungkinan terjadinya sengketa tak terhindarkan. Hal 
tersebut disebabkan beberapa faktor, di antaranya adalah perbedaan pemahaman antara konsumen dengan LJK mengenai suatu produk atau layanan jasa keuangan terkait. Sengketa juga dapat disebabkan kelalaian konsumen atau LJK dalam melaksanakan kewajiban dalam perjanjian terkait produk atau layanan dimaksud. Penyelesaian sengketa harus dilakukan di LJK lebih dahulu.

Dalam Peraturan OJK tentang Perlindungan Konsumen Sektor Jasa Keuangan diatur bahwa setiap LJK wajib memiliki unit kerja dan atau fungsi serta mekanisme pelayanan dan penyelesaian pengaduan bagi konsumen. Jika penyelesaian sengketa di LJK tidak mencapai kesepakatan, konsumen dapat melakukan penyelesaian sengketa di luar pengadilan atau melalui pengadilan. Penyelesaian sengketa di luar pengadilan dilakukan melalui Lembaga Alternatif Penyelesaian Sengketa (LAPS).

Menurut peraturan Otoritas Jasa keuangan Nomer 1/POJK.07/2013 tentang Alternatif penyelesaian Sengketa, Lembaga Alternatif penyelesaian Sengketa (LAPS) mempunyai mekanisme dalam penyelesaian sengketa Melalui Lembaga Alternatif Penyelesaian Sengketa dimana mekanisme tersebut terdiri dari :
a. Konsumen menyampaikan permohonan penyelesaian sengketa.
b. Setelah itu akan melalui proses verivikasi terhadap dokumen permohonan.
c. Adanya konfirmasi penerimaan permohonan Penyelesaian Sengketa.
d. Pemilihan atau penunjukan pihak yaitu mediator, arbiter, ajudikator.
e. Terjadinya proses penyelesaian sengketa melalui jalur mediasi, ajudikasi, arbitrase.
f. Tercapainya kesepakatan.

Berdasarkan hasil wawancara dengan Kasubag Bidang Pasar Modal yaitu bapak Milado Pani dijelekaskan prinsip prinsip dalam Lembaga Alternatif Penyelesaian Sengketa yang terdiri dari:
1) Prinsip
Lembaga
Alternatif
Penyelesaian Sengketa LAPS
Berdasarkan Peraturan Otoritas Jasa Keuangan Nomor 1/POJK.07/2014 tentang Lembaga Alternatif Penyelesaian Sengketa di Sektor Jasa Keuangan, LAPS memiliki prinsip sebagai berikut:

Prinsip aksesibilitas Layanan penyelesaian sengketa mudah diakses oleh konsumen dan mencakup seluruh Indonesia.

a) Prinsip independensi Lembaga Alternatif Penyelesaian Sengketa (LAPS) memiliki organ pengawas untuk menjaga dan memastikan independensi SDM LAPS. Selain itu Lembaga Alternatif Penyelesaian Sengketa (LAPS) juga memiliki sumber daya yang memadai sehingga tidak tergantung kepada Lembaga Jasa Keuangan tertentu.

b) Prinsip keadilan Mediator di Lembaga Alternatif Penyelesain Sengketa (LAPS) bertindak sebagai fasilitator dalam rangka mempertemukan kepentingan para pihak dalam memperoleh kesepakatan penyelesaian sengketa, sedangkan ajudikator dan arbiter wajib memberikan alasan tertulis dalam tiap putusannya. Jika ada penolakan permohonan penyelesaian sengketa dari konsumen dan Lembaga Jasa Keuangan, LAPS wajib memberikan alasan tertulis.

c) Prinsip efisiensi dan efektivita Lembaga Alternatif Penyesaian Sengketa (LAPS) mengenakan biaya murah kepada konsumen dalam penyelesaian sengketa Penyelesaian 
sengketa di Lembaga Alternatif

Penyelesaian Sengketa (LAPS)

dilakukan dengan cepat. Pelaksanaan putusan diawasi Lembaga Alternatif Penyelesaian Sengketa (LAPS.)

2) Layanan Penyelesaian Sengketa di Lembaga Alternatif Penyelesaian Sengketa (LAPS)

a) Mediasi Cara penyelesaian sengketa melalui pihak ketiga (mediator) untuk membantu pihak yang bersengketa mencapai kesepakatan.

b) Ajudikasi Cara penyelesaian sengketa melalui pihak ketiga (ajudikator) untuk menjatuhkan putusan atas sengketa yang timbul di antara pihak yang dimaksud. Putusan ajudikasi mengikat para pihak jika konsumen menerima. Dalam hal konsumen menolak, konsumen dapat mencari upaya penyelesaian lainnya.

c) Arbitrase Cara penyelesaian suatu sengketa perdata di luar pengadilan yang didasarkan pada perjanjian arbitrase yang dibuat secara tertulis oleh para pihak yang bersengketa. Putusan arbitrase bersifat final dan mengikat para pihak.

\section{c. Penyelesaian Sengketa Melalui Bandan Arbitrase Pasar modal Indonesia (BAPMI)}

BAPMI dibentuk karena adanya desakan dan kebutuhan dari pelaku pasar modal untuk menyelesaikan sengketa dengan cepat dan ditangani orang yang ahli dalam pasar modal melalui Alternatif Penyelesaian Sengketa. Secara umum BAPMI memiliki struktur organisasi yang telah berjalan sesuai dengan cara kerja yang disepakati, dimana pengurus lembaga adalah semua yang terlibat di dalamnya, dari dewan pengawas hingga anggota. BAPMI berwenang untuk menyelesaikan sengketa perdata Pasar Modal yang para pihaknya telah membuat perjanjian tertulis dan secara tegas memilih BAPMI untuk menyelesaikan sengketa.

Setelah sepakat membawa sengketa Pasar Modal yang timbul diantara mereka ke BAPMI. Artinya para pihak telah setuju untuk menggunakan peraturan prosedur BAPMI, maka sengketa tersebut diselesaikan dibawah penyelenggaraan BAPMI berdasarkan peraturan BAPMI sampai putusan dibacakan. Putusan arbitrase didaftarkan oleh BAPMI pada kantor kepaniteraan pengadilan negeri setempat dalam waktu selambat-lambatnya 30 (tiga puluh) hari sejak ditetapkannya putusan arbitrase dan harus dilaksanakan oleh para pihak selambat- lambatnya 30 (tiga puluh) hari sejak pendaftaran.

Putusan arbitrase tidak ada upaya banding atau kasasi. Namun sesuai dengan Pasal 70 Undang-Undang Nomor 30 Tahun 1999 tentang Aribitrase dana Alternatif Penyelesaian Sengketa, dimungkinkan untuk melakukan pembatalan putusan arbitrase jika terbukti adanya tipu muslihat, dokumen atau surat palsu dan dokumen menentukan yang disembunyikan dengan sengaja. Jika terbukti melakukan hal tersebut maka putusan BAPMI dapat dibatalkan oleh Pengadilan Negeri.

\section{B. Akibat Hukum Bagi Para Pihak Yang Bersengketa Pada Kegitaan Usaha Pasar Modal Indonesia.}

Berdasrkan Hasil wawancara dengan Kasubag Pasar Modal Bapak Milado Pani dari kantor Otoritas Jasa keuangan (OJK) Provinsi Lampung dijelaskan bahwa akibat hukum yang diperoleh para pihak yang 
bersengketa dala kegitaan usaha jasa keuangan pasar modal di Indonesia adalah bersifat Final An Bading.

\section{Final And Banding}

Putusan arbitrase adalah bersifat final dan mengikat (final and binding) kedua belah pihak. Dalam hal putusan tidak dilaksanakan secara sukarela, putusan dilaksanakan berdasarkan perintah ketua pengadilan negeri atas permohonan salah satu pihak (pasal 61 Undang-Undang Alternatif Penyelesaian Sengketa.

Putusan Arbitrase Nasional

Hal ini dijabarkan dalam Pasal 59 Undang-Undang Alternatif Penyelesaian Sengketa sebagai berikut:

1) Dalam waktu paling lama 30 hari terhitung sejak tanggal putusan diucapkan, lembar asli atau salinan otentik putusan arbitrase diserahkan dan didaftarkan oleh arbiter atau kuasanya kepada panitera Pengadilan Negeri.

2) Penyerahan dan pendaftaran sebagaimana dimaksud dalam ayat (1), dilakukan dengan pencatatan dan penandatanganan pada bagian akhir atau di pinggir putusan oleh panitera pengadilan negeri merupakan akta pendaftaran.

3) Arbiter atau kuasanya wajib menyerahkan putusan dan lembar asli pengangkatan sebagai arbiter atau salinan otentiknya kepada panitera pengadilan negeri.

4) Tidak dipenuhinya ketentuan sebagaimana dimaksud dalam ayat (1), berakibat putusan arbitrase tidak dapat dilaksanakan.

5) Semua biaya berhubungan dengan pembuatan akta pendaftaran dibebankan kepada para pihak.
Berdasarkan hasil wawancara dengan Kasubag Pasar Modal Bapak Milado Pani paada Kantor Otoritas Jasa Keuangan (OJK) Provinsi Lampung dapat dijelaksan bahwa akibat hukum yang didapatkan oleh para pihak yang bersengketa pada sektor jasa keuangan Pasar Modal jika penyelesaian tersebut melalui Badan Aribtrase Pasar Modal Indonesia (BAPMI) yakni Putusan Mengikat yang diberikan oleh Badan Arbitrase Pasar Modal indonesia BAPMI bersifat final dan mengikat para pihak yang memintanya, tidak dapat diajukan perlawanan atau bantahan. Pendapat Mengikat itu harus segera dilaksanakan dalam waktu 30 hari sejak diterbitkan. Setiap tindakan yang bertentangan dengan Putusan Mengikat merupakan pelanggaran perjanjian.

Apabila ada pihak yang tidak menaati Putusan Mengikat Badan Arbitrase Pasar Modal Indonesia (BAPMI), maka:

1. Tindakan tersebut dianggap sebagai pelanggaran perjanjian;

2. Pihak yang berkepentingan dan/ atau badan arbitrase pasar modal indonesia (bapmi) dapat menyampaikan pengaduan kepada pengurus dari asosiasi/organisasi di mana ia menjadi anggota;

3. Asosiasi/organisasi dimana pihak yang berkepentingan menjadi anggota dan/ ataubadan arbitrase pasar modal indonesia (bapmi) dapat menyampaikan pengaduan kepada otoritas di bidang pasar modal dan seluruh anggota badan arbitrase pasar modal indonesia (bapmi).

Setelah adanya Putusan yang dikeluarkan oleh Badan Arbitrase Pasar Modal Indonesia makan putusan yang sudah ditetapkan apaabila diteriam oleh masing-masing pihak maka putusan 
tersebut harus didaftrakan kepada Pengadilan Negeri Dearah Hukum yang berwenang setelah dilakukan pendaftran dan putusan dijalankan maka selesai Proses Penyelesaian Sengketa tersebut. Akan tetapi jika putusan tersebut ditolak oleh salah satu pihak maka dapat dilakukan Fiat Eksekusi dan juga proses penyelesain sengketa melalui Litigasi.

Fiat Eksekusi yang dimaksud dalam Sengketa Pasar Modal ialah merupakan eksekusi yang dilaksanakan oleh Kantor Lelang Negera setelah mendapat persetujuan dari Ketua Pengadilan Negeri setempat, permohonan fiat eksekusi ini pihak Pengadilan Negeri cukup melakukan pemeriksaan terhadap syarat-syarat formal yang telah ditentukan. Berdasarkan pada fiat tersebut disertai dengan terbitnya surat perintah penjualan lelang, maka Kantor Lelang melakukan penjualan atas objek saham di muka umum. Akan tetapi sebelum menerbitkan fiat eksekusi tersebut Ketua Pengadilan Negeri memberikan peringatan kepada debitur agar dalam jangka waktu tertentu debitur penuhi kewajibannya secara sukarela. Apabila peringatan tersebut tidak dapat dipenuhi maka Ketua Pengadilan Negeri menerbitkan surat perintah penyitaan untuk selanjutnya diterbitkan perintah penjualan lelang kepada Kantor Lelang Negara.

Sebelum pelelangan dilaksanakan harus didahului pengumuman sebanyak dua kali berturut-turut dengan tenggang waktu 15 hari melalui surat kabar. Setelah semua persyaratan lelang terpenuhi kemudian Kantor Lelang Negara melakukan pelelangan atas objek secara umum dimana hasilnya digunakan untuk melunasi utang debitur dan jika ada sisanya akan dikembalikan kepada debitur.

Selain itu juga jika putusan yang diterbitkan oleh Lembaga Alternatif
Penyelesaian Sengketa yang ada pada sektor jasa keuangan Pasar Modal yaitu Badan Arbitrase Pasar Modal Indonesia (BAPMI), tidak bisa diterima oleh para pihak yang bersengketa maka dapat dilanjutkan dengan jalur Litigasi. Upaya hukum dengan jalur Litigasi berbeda dangan upaya hukum melalui jalur Non Litigasi, jika melalui jalur Litigasi maka para pihak dapat mengajukan Laporan terlebih dahulu kepada instansi terkait setelah itu para pihak akan diproses sesuai dengan Standar Oprasional yang berlaku, setalah semua proses berjalan maka akan dikeluarkan putus yang bersifat mengikat dan wajib dilaksanakan jika ada putusan itu kembali tidak dapat diterima maka upaya hukum selanjutnya adalah Banding, jika dalam Proses Banding para pihak masih tidak bisa menerima putusan yang ada maka akan dilakukan upaya hukum terakhir yaitu Peninjaun Kembali atau (PK), putusan Peninjaun Kembali (PK) harus diterima dan dijalankan. Sesuai dengan ketentuan akibat hukum dalam proses Penyelesaian Sengketa melalui jalur Litigasi bersifat Ultimum Remedium.

Berdasarkan hasil urain diatas, dapat dianalisis bahwa penyelesaian sengketa non litigasi yang ditempuh para pihak jika penyelesaian secara Internal tidak mencapai keputasan maka bisa difasilitasi oleh Otoritas Jasa keuangan dan bila selama proses mediasi di Otoritas Jasa Keuangan tidak mencapai damai maka sengketa tersebut dilanjutkan pada Lembaga Alternatif Penyelesaian Sengketa (LAPS) dengan mengikuti prosedur yang berlaku dan menjalankan Proses yang sudah ditentukan seperti tahap Mediasi, Ajudikasi, Arbitrase. Sengketa yang sedang berjalan akan dilakukan prosedur penunjukan Pihak Ketiga dimana Pihak ketiga tersebut sudah diatur dan ditentukan 
sesuai dengan sektor jasa keuangan masing-masing, jika bicara tentang sengketa Pasar modal maka sengketa tersebut akan diselesaikan melalui Badan Arbitrase Pasar Modal Indonesia (BAPMI). Tetapi masih dalam pengawasan Lembaga Alternatif Penyelesaian Sengketa (LAPS) terhadap kesepakatan yang dibuat.

Apabila para pihak tidak menjalankan putusan tersebut dalam batas waktu yang sudah ditetapkan maka akan diangap pelanggaran janji. Dan sengekta tersebut dapat dilanjutkan dengan Proses dan Prosedur Litigasi sebagai upaya hukum Ultimum Remedium. Penulis dapat menyimpulkan dari penjelasan diatas bahwa Proses dan Prosedur yang barlaku pada Penyelesaian Sengketa Pasar Modal Di Indonesia diawali dengan tahap mediasi yang difasilitasi oleh Otoritas Jasa Keuangan (OJK) jika pada tahap ini tidak ditemukan sepakat atau Deadlock, maka dapat dilanjutkan oleh Lembaga Alternatif penyelesain Sengketa (LAPS), apabila itu sengketa Pasar Modal maka penyelesaian akan dilakukan oleh Badan Arbitrase Pasar Modal Indonesia selaku lembaga resmi yang ditentukan oleh Lembaga Alternatif Penyelesaian Sengketa (LAPS) dalam sektor Pasar Modal.

Setalah terdapat putusan Badan Arbitrase Pasar Modal Indonesia maka para pihak yang bersengketa wajib menjalankan putusan tersebut yang dinamakan eksekusi putusan Badan Arbitrase Pasar Modal Indonesia. Apabila putusan tidak dilaksanakan maka dapat ditempuh Jalur Litigasi sebagai upaya hukum Ultimum Remedium. Akibat hukum bagai para pihak yang bersengketa pada sektor keuangan Pasar Modal di Indonesia baik itu melalui jalur Litigasi maupun Non Litigasi sama-sama berakibat Hukum tetap dan mengikat masing-masing pihak, jika sudah terdapat putusan yang mengikatb dan tidak dijalankan maka pihak yang tidka menjalakan dapat dikatakan wanprestasi atau juga perbuatan melawan hukum.

\section{PENUTUP}

\section{A. Kesimpulan}

Berdasarkan hasil penelitian dan pembahasan ditas maka dapat disimpulkan bahwa:

1. Proses dan Prosedur penyelesain sengketa Pasar Modal dapat memalui jalur Litigasi Maupun Non Litigasi, apabila para pihak memilih Jalur Non Litigasi maka Prosedur yang dilakukan dimulai pada Pengaduan Kepada Otoritas Jasa Keuangan (OJK) lalu akan difasilitasi oleh Otoritas Jasa Keuangan (OJK). Apabila Deadlock maka akan dilanjutkan dengan Proses penyelsaian sengketa Oleh Lembaga Alternatif Penyelesaian Sengketa (LAPS) dan berprosedur dimana sengketa tersebut akan diselesaikan oleh Badan Arbitrase Pasar Modal Indonesia (BAPMI), selalu lembaga resmi yang dibentuk Lembaga Alternatif Penyelesaian Sengketa (LAPS). Untuk meyelsaikan sengketa pada sektor keuangan Pasar Modal, namun apabila para pihak tidak bisa menerima putusan yang ditetapkan oleh Badan Arbitrase Pasar Modal (BAPMI) maka sengketa tersebut bisa ditempuh melalui jalur Litigasi.

2. Akibat Hukum dalam putusan penyelesaian sengketa pasar modal bersifat Final\&Banding atau mengikat para pihak dan wajib dijalankan juga diterima para pihak. Akibat hukum tersebut didapatkan baik penyelesian sengketa jalur Litigasi maupun Non 
Litigas, jika ada pihak yang tidak menjalakan maka dapat dikatakan wanprestasi atau perbuatan melawan hukum

\section{B. Saran}

1. Seharusnya Otoritas Jasa keuangan (OJK) lebih mensosialisasikan proses dan prosedur penyelesaian sengketa kepada pihak yang melakukan kegiatan usaha di sektor jasa keuangan Pasar Modal maupun masyarakat yang memiliki kegiatan pasar modal bahwa penyelesaian sengketa pasar modal tidak hanya melalui Litigasi tetapi dapat dilakukan melalui jalur Non Litigasi yaitu melalui Otoritas Jasa Keuangan yang mana jika penyelesaian tidak ada kata sepakat antara kedua belah pihak maka sengketa akan di selesaikan sesuai proses dan prosedur yang telah diatur oleh Lembaga Alternatif Penyelesaian Sengketa (LAPS) melalui Badan Abitrase Pasar Modal Indonesia (BAPMI).

2. Sebaiknya pihak yang melakukan kegiatan usaha Pasar Modal mengikuti proses kegiatan usaha yang telah diatur dalam Undang-Undang Nomor 8 tahun 1995 tentang Pasar Modal. Yang mana seharusnya dilakukan dengan data-data sebenarnya atau tidak memanipulasi data untuk melakukan kegitan tersebut dan pihak yang bersengketa seharusnya dapat mengikuti proses penyelesaian yang telah ditetapkan dengan cara Litigasi maupun Non Litigasi, agar tidak terjadi wanprastasi atau perbuatan melawan hukum.

\section{DAFTAR PUSTAKA}

\section{A. BUKU-BUKU}

Ana Rokhmatssa. 2017. Hukum Investasi \& Pasar Modal. Sinar Grafika, Jakarta.

Jusuf Anwar. 2005. Pasar Modal Sebagai Sarana Pembiayaan dan Investas, Alumni Bandung.

Jusuf Anwar. 2008. Seri Pasar Modal 2. Penegakan Hukum Dan Pengawasan Pasar Modal Indonesia, PT Alumni Bandung.

Munir fuady. 2003. Alternatif Penyelesaian Sengekta. Citra Aditya Bakti, Bandung.

Tavinayati dan Yulia Qamariyanti. 2009. Hukum Pasar Modal di Indinesia.Suua Grafika, Jakarta.

\section{B. Undang-Undang Dan Peraturan Lainnya}

Undang-Undang Nomor 8 Tahun 1995 tentang Pasar Modal.

Undang-Undang Nomor 21 Tahun 2011 tentang Otoritas Jasa Keuangan

Undang-Undang Nomor 30 Tahun 1999 tentang Arbitrase dan Alternatif Penyelesaian Sengketa

Peraturan Otoritas Jasa Keuangan Nomor 1/POJK.07/2013 tentang Perlindungan Konsumen.

Peraturan Otoritas Jasa Keuangan Nomor 1/POJK.07/2014 tentang Alternatif Penyelesaian Sengketa

Peraturan Otoritas Jasa Keuangan Nomor 13/POJK.02/.2018 tentang Inovasi Keuangan Digital Di Sektor Jasa Keuangan. 